\title{
DRY MATTER PRODUCTION OF 'MASSEY BASYN' YORKSHIRE FOG (HOLCUS LANATUS)
}

\author{
B. R. W atkin and G. S. Robinson
}

Agronomy Department, Massey University, Palmerston N orth

\section{Abstract}

In two experiments carried out at Massey University it was shown that 'Massey Basyn' Yorkshire fog gave similar dry matter yields to Ruanui, Ariki, and Manawa ryegrasses and promoted lamb liveweight gains similar to those obtained on Ruanui ryegrass pastures. Lamb birthweights were significantly lower on Yorkshire fog than on ryegrass pastures. Yorkshire fog was relatively slow to establish, but low grass production in the early stages was balanced by increased clover growth. The seasonal production of Yorkshire fog was well distributed. Yorkshire fog suppressed white clover and volunter species more than did the ryegrasses, particularly in spring, when Yorkshire fog plots gave lower yields than ryegrass plots.

\section{INTRODUCTION}

YoRKSHIRE FOG (Holcus lanatus) is not highly regarded as a grazing species in New Zealand despite its presence in pastures over a wide range of soil and climatic conditions. The recognized lack of palatability of this grass has been mainly responsible for this situation together with the opinion widely held by farmers and agriculturalists that Yorkshire fog is low yielding and more suited to low fertility soils. These conclusions are the result of experience with naturally occurring types of Yorkshire fog. This paper reports some results of two grazing trials using a selection made by Jacques (1962) under conditions of moderate to high fertility.

\section{EXPERIMENT A}

The first trial was carried out at Massey University on a Tokomaru silt loam (N.Z. Soil Bureau, 1954), which had been adequately drained by moles and tiles. A randomized block layout was used incorporating three replications, two of which were sown on land that had been in crop the previous year, and one on Band which had been under mixed pasture for severall years. The trial was originally designed to compare, separately, 'Grasslands Ariki' ryegrass (Barclay, 1963) with the now-called 'Grasslands Manawa' and 'Grasslands Ruanui' ryegrasses and was amended to include a fourth treatment of 'Massey Basyn' York- 
shire fog. Each plot was approximately 0.03 ha in area and was fenced separately. The plots were sown by hand, on March 30, 1961 , on a Cambridge-rolled surface together with $376 \mathrm{~kg} / \mathrm{ha}$ serpentine-superphosphate- and then covered by a light harrow. The ryagrasses were sown at $20 \mathrm{~kg} / \mathrm{ha}$ and Yorkshire fog at $11 \mathrm{~kg} / \mathrm{ha}$, each with $3.3 \mathrm{~kg}$ white clover and $3.3 \mathrm{~kg}$ red clover per hectare.

Establishment of all species was satisfactory and the experimental area was grazed on three occasions prior to the erection of the fences. on August 10 in preparation for yield measurements.

The method of management used up to January was to graze each species intensively whenever it reached a height of about $15 \mathrm{~cm}$ over a period of 3 or 4 days. In each plot dry matter pro duction was measured in a caged enclosure by cutting or plucking after each grazing to the level of the grazed herbage. However, after the first year the method was changed because it became apparent that the more unpalatable Yorkshire fog was taking a longer time to graze off than the ryegrasses, and sometimes it was difficult to achieve adequate defoliation. During the remainder of the trial, therefore, a separate flock was used for each species, the numbers being regulated so that each plot was grazed in about 3 or 4 days, after which the sheep moved on to the next replicate. About 7 days elapsed therefore before the sheep returned to a particular replicate. Yield measurements were taken whenever the herbage in the enclosure reached 15 to $20 \mathrm{~cm}$ in height. The enclosure was then placed on an adjacent trimmed area. In this way the palatability problem was overcome as it was found that the sheep grazing Yorkshire fog all the time ate it readily. Adjustments to all four flocks had to be made occasionally depending on growth conditions but no difficulties were encountered, as holding plots of each species were available from which sheep for any particular flock could be selected.

Measurements commenced in September 1961 and continued through to March 1964.

Samples were taken from each enclosure for dry matter determinations. Herbage dissection was undertaken by the Seed Testing Station, Department of Agriculture.

\section{RESULTS}

\section{Total Production}

(1) In the pre-measurement period - i.e., the first six months after sowing - Manawa ryegrass was noticeably more pro- 
ductive than the other species. This superiority, however, disappeared with the spring conditions.. Yorkshire fag was much slower than the ryegrass to establish.

(2) The low production of Yorkshire fog continued into the early measurements but increased clover growth occurred at this stage which raised plot yield up to that of Ruanui and Manawa. The dry matter yields per hectare are given in Table 1.

Over the whole period of the trial, Yorkshire fog plats narrowly, outyielded the three ryegrass plots.

Quite marked differences occurred in the proportions of other species associated with the main grass sown. Yorkshire fog inhibited clover growth to the extent that the total production included ody $8 \%$ of clover. This figure was very variable, ranging from $2 \%$ in winter to $19 \%$ in summer. The aggressive nature of fog was also seen in the low content of "other species" recorded. Of the ryegrasses, there was less clover (15\%) and other species in the Ariki plots compared with that in the Manawa $(25 \%)$ and Ruanui $(25 \%)$ plats. This agrees with other experiments (Sears and Brougham, 1963) and occurred despite light seeding rates and good grazing control.

\begin{tabular}{lrrrrr} 
TABLE & 1: TOTAL & $\begin{array}{c}\text { DRY MATTER YIELD } \\
(\mathrm{kg} / \mathrm{ha})\end{array}$ & \\
\hline & Ariki & Manawa & Ruanui & Yorkshire Fog \\
\hline Sep. 1961 to Mar. 1962 & 6520 & 5750 & 5860 & 5910 \\
April 1962 to Mar. 1963 12630 & 13420 & 12850 & 14180 \\
April 1963 to Mar. 1964 & 15810 & 15190 & 16340 & 17710 \\
Mean & 11660 & 11450 & 11680 & 12600 \\
LSD 5\% & 827 & & & \\
\hline
\end{tabular}

\section{Seasonal Production}

Seasonal yields. of the respective pastures are presented in Table 2.

It is noteworthy that the Yorkshire fog pasture was productive' at all seasons of the year. Fag has always been regarded as a good winter grower and this is borne out by the records of these two years. However, it has not been considered very useful in the summer, though in this trial the selected strain proved most productive. Rainfall during these periods was close to the average and was well distributed in each year. Yorkshire fog plots did not 
yield as well as ryegrass in the spring despite the fact that in terms of grass production alone they were considerably higher. At this stage clovers were excluded more completely than at any other time by the Yorkshire fog. Ariki ryegrass showed a more even spread of production throughout the year than the other ryegrasses.

TABLE 2: TOTAL SEASONAL DRY MATTER YIELDS (Mean of 3 replications, $\mathrm{kg} / \mathrm{ha}$ )

\begin{tabular}{lcccc}
\hline & Ariki & $\begin{array}{c}\text { Grasslands Grasslands } \\
\text { Manawa }\end{array}$ & $\begin{array}{c}\text { Massey } \\
\text { Ruanui }\end{array}$ & $\begin{array}{c}\text { Basyn' } \\
\text { Yorkshire Fog }\end{array}$ \\
\hline Spring 1961 & 3890 & 3430 & 3510 & 3380 \\
Summer 1961-2 & 2630 & 2310 & 2350 & 2510 \\
Autumn 1962 & 2460 & 1830 & 2110 & 2350 \\
Winter 1962 & 1520 & 1830 & 1440 & 2210 \\
Spring 1962 & 4950 & 5540 & 5200 & 5000 \\
Summer 1962-3 & 3700 & 4230 & 4100 & 4630 \\
Autumn 1963 & 2120 & 1890 & 2060 & 2740 \\
Winter 1963 & 2020 & 2420 & 1920 & 2870 \\
Spring 1963 & 5680 & 6050 & 6610 & 5790 \\
Summer 1963-4 & 6000 & 4830 & 5770 & 6320 \\
\hline
\end{tabular}

\section{EXPERIMENT B}

The second trial was carried out at Massey University on an Ohakaa silt loam and sown in autumn 1967 with $376 \mathrm{~kg} / \mathrm{ha}$ of superphosphate and $125 \mathrm{~kg}$ of nitrate of potash. The grass species compared included Ruenui ryegrass and 'Massey Basyn' Yorkshire fog sown at $22 \mathrm{~kg} / \mathrm{ha}$ and $11 \mathrm{~kg} / \mathrm{ha}$, respectively, and each with $3.3 \mathrm{~kg} / \mathrm{ha}$ of 'Grasslands Huia' white clover.

Establishment was successful and the experimental1 area grazed judiciously over the following 9 months by which time all pastures were. considered good, productive stands of the appropriate species. The pasture species were then set-stocked with Romney ewe hoggets at 26 ewes/ha, each paddock being. 0.27 ha with 2 replicates. Animals were weighed at approximately monthly intervals. In the second year the ewes were mated with a polledDorset ram.

\section{RESULTS}

Animal livewsights over the experimental period are presented in Fig. 1. Following the initial period, when ryegrass was superior to fog, animal liveweights showed a similar pattern of response to the two pastures. 


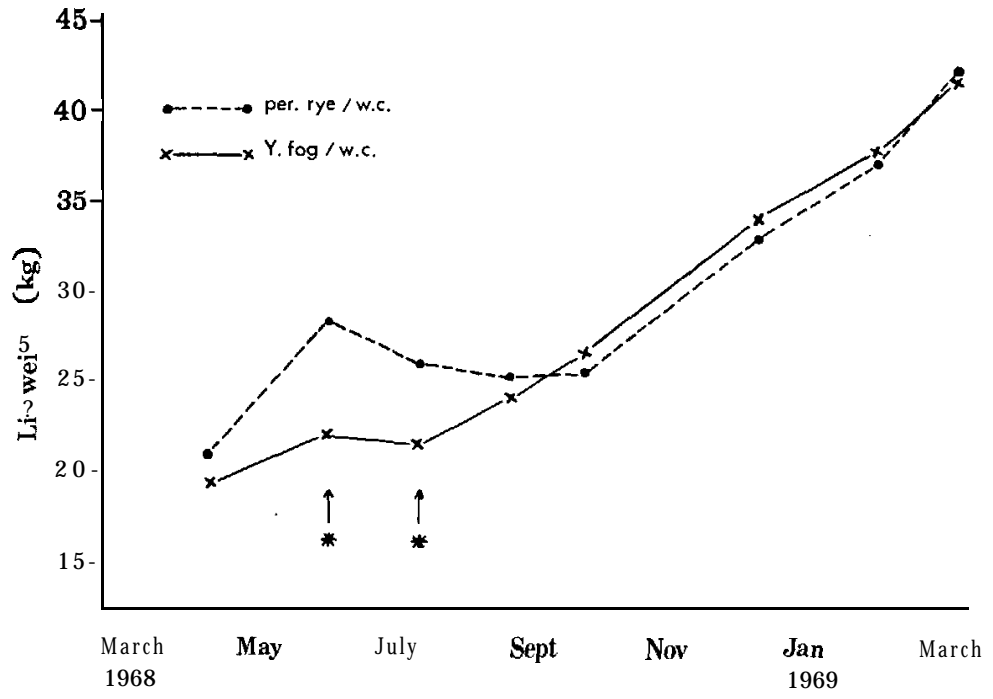

FIG. 1: Liveweight changes of ewe hoggets. (Note: Significant differences are marked with an asterisk.)

In the second year the first lamb drop of $86 \%$ was the same on both pastures.

The performance of the lambs is presented in Table 3 and shows a similar rate of liveweight gain $\mathrm{cm}$ both pastures. However, the birth weight of the lambs was significantly higher on the ryegrass than on the fog pasture.

TABLE 3: LAMB PERFORMANCE

\begin{tabular}{lcc}
\hline & $\begin{array}{c}\text { Birth Weighi } \\
(\mathrm{kg})\end{array}$ & $\begin{array}{c}\text { Daily Liveweight Gain } \\
(\mathrm{kg}) \\
(\text { Nov.-Dec. 1969) }\end{array}$ \\
\hline $\begin{array}{l}\text { Perennial ryegrass/white clover } \\
\text { Yorkshire fog/white clover }\end{array}$ & $\mathbf{4 . 2}$ & 0.195 \\
\hline
\end{tabular}

Fleece weights appeared to favour the ryegrass treatment slightly (namely, ryegrass $4.1 \mathrm{~kg}$; Yorkshire fog $3.9 \mathrm{~kg}$ ) although differences were not statistically significant,

\section{DISCUSSION}

The results of Experiment $A$ indicate that in terms of dry matter, 'Massey Basyn' Yorkshire fog has a similar productive capacity to the ryegrasses compared. Once the stock management 
procedure was altered, there was no evidence of a palatability problem. However, this very requirement must be recognized if Yorkshire fog is to be exploited.

Seasonal production of Yorkshire fog appeared to be well distributed with relatively good production in the winter and summer but poor production in the spring when clover suppression was most noticeable.

In Experiment B, liveweight gains of the hoggets on the two pastures were similar, apart from the early period when presumably the animals were adjusting to the Yorkshire fog diet. Lamb growth rates on the two pastures were also similar, although the perennial ryegrass trcatment produced heavier lambs at birth.

It should be recognized that these pastures were set-stocked at a high stocking rate throughout the whole year with little opportunity for the pastures to develop any length of feed. This is ccnsidered by the writers to be an important requirement in the grazing management of a Yorkshire fog/white clover pasture to ensure the maintenance of a good clover component and to prevent the development and accumulation of excessive dead herbage. Throughout the experimental period there was no apparent evidence of sward deterioration, with the fog and clover components appearing to withstand the relatively "high grazing pressure successfully.

\section{REFERENCES}

Barclay, P., 1963: Proc. N.Z. Grassld Ass., 25: 128. Jacques, W. A., 1962: Proc. N.Z. Grassld Ass., 24: 139.

N.Z. Soil Bureau, 1954: N.Z. Soil Bureau Bull. $n . s, 5$.

Sears, P. D.; Brougham, R. W., 1963: Proc. N.Z. Grassid Ass., 25: 148. 